\title{
Introduction: the importance of credit and money in understanding crises
}

\section{Louis-Philippe Rochon and Hassan Bougrine}

Over a century ago, in an aptly-titled article, Innes (1913) asked what we believe is one of the most important questions in monetary theory: 'What is money?' - a question Smithin (1999) would later revisit. While on the surface this question may appear to be simple enough, the answer, however, is far from simple. Indeed, many answers have been provided, from a number of perspectives and disciplines. Money can mean something very different to different scholars, and the answers provided often reflect the focus of one's research, thereby leading to different aspects of the same issue or question being explored in various degrees of detailed analysis. Indeed, money has many dimensions.

The study of money has certainly perplexed economists for decades, if not centuries, with no consensus in sight. However, two general approaches can be identified, which, following Schumpeter (1954/1994, p. 277), can be labelled real and monetary analyses respectively (see also Rogers, 1989, Ch. 1) - although other labels can also be used: orthodox versus heterodox, exogenous versus endogenous. Rochon and Rossi (2013) have further identified two distinct approaches to endogenous money within postKeynesian theory, referring to what they call the 'evolutionary' (Chick, 1986) and 'revolutionary' (Lavoie, 1992, 2014; Rochon, 1999) approaches to endogenous money.

Moreover, in the last few decades, many economists in the mainstream have come to accept some version of the endogeneity of money, as reflected for instance in the use of Taylor Rules, as in the New Consensus, or the Woodford (2003) model, although whether this can be considered endogenous has been questioned (see Monvoisin and Rochon, 2006). In this sense, some have argued that the lines between post-Keynesians and the mainstream appear somewhat blurred, and the endogeneity/exogeneity of money is no longer a distinguishable characteristic between the two approaches. For instance, according to Lavoie (2020), 'propounding a theory based on the endogeneity of money is insufficient to break away 
from mainstream economics: one also has to reject the existence of a natural rate of interest in a monetized economy'.

This, of course, comes down to how we define endogeneity. Lavoie is certainly correct to argue that we further need to reject the natural rate of interest - an issue at the core of Smithin's life-long research agenda otherwise what we end up having is some sort of endogeneity in the shortrun, with the central bank rate of interest gravitating to the natural rate in some long-run equilibrium. But we need to go beyond this.

Rochon (1999) suggested five arguments embedded in a true or revolutionary theory of endogenous money. Indeed, if we follow the logic of money's endogeneity, and the link between money and production, then a true definition of endogenous money must imply the following conditions:

(1) reverse causality between money and income;

(2) reverse causality between savings and investment;

(3) reverse causality between reserves, deposits and loans;

(4) the rate of interest is a pure exogenous variable or an administered price;

(5) the money supply is credit-led and demand-determined.

To which we should add the rejection of a natural rate of interest.

Seen in this light, it becomes clear that New Consensus models are still far from any sort of money endogeneity. Indeed, Fiebeger and Lavoie (2018) have recently argued that monetarism was simply folded into New Consensus models. This is consistent with Lavoie (2004, p. 16), who called New Consensus models 'old wine in a new bottle'.

What we are left with is a potpourri of ideas that make up mainstream theory and policy. On the one hand, while mainstream proponents have certainly recognized the ability of the central bank to set the rate of interest, they still believe that the overall objective of monetary policy is to gravitate towards the natural rate of interest. In addition, inflation is still seen, if not as a monetary phenomenon, certainly as a monetary policy phenomenon. One therefore wonders, despite advances in the last two decades, whether or rather how far the mainstream has gotten from the ideas of Milton Friedman. For instance, quantitative easing is still based on the old money multiplier model, where banks would lend out the excess reserves being created. Old wine indeed.

Regardless, the orthodox approach remains the dominant view in the profession. Textbooks still explain money largely as a commodity among many others, whose supply is determined by the central bank, independently of economic activity. There are still plenty of textbooks that still depict the money supply curve as vertical. In other words, money 
is simply a veil behind which real economic activity still operates: this is Schumpeter's real analysis.

Post-Keynesians (at least most of them) reject this approach, and in fact dig deeper: they not only reject the mainstream view of money, they also reject the mainstream explanation regarding the origins of money, and the links between money and inflation.

First, they reject the idea that money somehow evolved out of bartering. After all, anthropological evidence indicates the link between money and barter is at best tenuous. As Wray (1990, p. 4) claims, 'In fact, an examination of anthropological evidence reveals that early societies were not barter economies, that markets did not spring forth from barter, and that money was not invented to facilitate exchange'. Barter may therefore not have existed on a wide scale, or at least it was not such a cumbersome activity that required a solution. Barter was not a central element of economic life (Wray, 1990). ${ }^{1}$ First, primitive societies tended to be rather self-sufficient. Second, anthropologists question the nature of the ceremonies that many economists have come to accept as barter. In fact, according to some, these acts were highly ceremonial and religious in nature, often aimed at fostering new relationships between clans or reinforcing existing ones, often through marriage, in order to forge strategic alliances in times of war. Indeed, according to Malinowsky (1922, p. 66), the purpose for exchanging goods was 'to exchange articles which are of no practical use'. In fact, Polanyi (1971, p. 74) argues that

occasionally the identically same object is exchanged back and forth between the partners, thus depriving the transaction of any conceivable economic purpose or meaning. ... The sole purpose of the exchange is to draw relationships closer by strengthening the ties of reciprocity.

The barter fable, therefore, appears to be just that: a fable (Servet, 1994). According to Heinsohn and Steiger (1989, p. 180), 'The concept of a pure barter economy from which the monetary economy devolves is not more than a historical speculation and does not correspond to the true course of history'.

If money did not evolve from barter, then how can we explain the existence of money? How is it introduced into active circulation? If not by a central authority, how? After all, if money exists, where does it come from and how is it created?

We cannot possibly do justice to this question here, but suffice it to say that many historians, including Mitchell Innis, and even Keynes, argue that money in ancient societies has always taken the form of credit. Coins have value because of the promise of debt they represent and not because of the 
metal of which they are made. Other items such as pottery, wood sticks, paper, and so on have been used to record the debt/credit relationship between the parties to an exchange.

Second, regarding the link between money and inflation, postKeynesians and heterodox economists in general would argue that inflation is the result of conflict over the appropriate distribution of income. In this sense, it is not in general related to excess demand considerations (see Rochon and Setterfield, 2012).

For post-Keynesian economists, including the proponents of the monetary circuit in France and Italy, the answer lies in the macroeconomic link between bank credit, production and money. Post-Keynesians believe that real analysis has no application in a world that is essentially monetary in nature. In other words, there is a direct connection between the existence of money and economic activity: money and production are strictly related to one another, through the need of the private sector to finance production through the emission of bank loans (Rochon, 1999). In a way, the theory of production is rooted in the theory of debt, and therefore the rejection of Say's Law. Far from being a veil, one cannot disassociate money from the overall economic activity. This is the very nature of money, and the meaning of Keynes's idea of a 'monetary economy of production'. Money is not neutral.

The emphasis is therefore on credit demand, not money demand. The primary emphasis is the relationship between loans, debt and the resulting creation of money; discussions over the various functions of money, whether as a store of value or a unit of account are secondary, or at least separate from the discussion over the creation of money. What money does once it is created is certainly important, but not as important as how it is created and how it enters circulation (Rochon, 1999). As Keynes (1971, p. 197) writes:

Credit is the pavement along which production travels and the bankers if they knew their duty, would provide the transport facilities to just the extent it is required in order that the productive powers of the community can be employed at full employment.

Banks may or may not want to validate this demand, but they are always prepared to do so as long as borrowers are considered creditworthy, i.e. deemed able to reimburse the loan with interest.

All this, of course, is well known, and the work of Marc Lavoie and Mario Seccareccia over the last 35 years has certainly contributed to the large heterodox and post-Keynesian literature on this topic. Both authors have contributed significantly to the theory of endogenous money, 
monetary policy and central banking in general. In doing so, interesting questions regarding the possibility of crises emerge.

Indeed, one possible source of crises undoubtedly is the behaviour of banks. As Keynes tells us, banks are 'special', and 'if they knew their duty', banks can have obvious benefits for output and growth. But what if they don't perform their duty? If investment and production are financed, at least partly by bank credit, what if banks do not lend because of their overall pessimistic outlook on expected aggregate demand in the (near) future (see Rochon, 2006)?

The Great Financial Crisis that started in 2007/8 showed us how bad lending contributed to breaking the back of the proverbial economic camel. In both cases, either in refusing to lend or in making too many bad loans, banks are indeed 'special' and their behaviour must not only be monitored, but perhaps severely regulated (Kregel and Tonveronachi, 2014). Some have even called for a greater role of public banks (Bougrine and Seccareccia, 2013; Marshall and Rochon, 2019).

Finally, the issue of income inequality and distribution must be included into the discussion of crises, as it relates directly to aggregate demand. Here, the pioneering work of both Lavoie and Seccareccia, on linking monetary policy to income distribution is of paramount importance. The focus here is on the rate of interest as a distributive variable, where conflict between the distribution of income between rentiers and workers take centre stage. Changes in the rate of interest are transmitted to the real economy not only through the cost of borrowing and lending, but also through income.

The horrible consequences of these inequalities have been exposed by the most recent Coronavirus pandemic. Indeed, the pandemic has exposed the inner contradictions of the capitalist system itself; and showed that availability of - and universal access to - health care cannot be subject to profit calculations. If we count only the human death toll, it appears that workers and the poor are among the hardest hit: some statistics indicate that in the USA, 70 percent of the deceased are black. Also, when the health crisis forced businesses to close down, governments around the world came to the rescue of corporations through unprecedented fiscal stimuli - thus proving the class nature of the State.

\section{STRUCTURE OF THE BOOK}

The 17-chapter book is divided into two sections. Part 1, entitled 'Money, Income Distribution and Post-Keynesian Economics', contains 11 contributions. The opening chapter, by Louis-Philippe Rochon and Hassan 
Bougrine, discusses the pioneering work of Marc Lavoie and Mario Seccareccia, and celebrates this long-lasting friendship and cooperation.

Chapter 2, by Robert Guttmann, discusses the outstanding contributions of Marc Lavoie and Mario Seccareccia. Guttmann argues that they have each advanced heterodox monetary theory, especially its post-Keynesian variant, in clarifying the modus operandi of endogenous money creation, the link between money and credit in a cyclical dynamic engendering financial instability from within the system, the strategic importance of liquidity and its paradox, interest rates and their shifting structure, as well as the at-times contradictory intervention logic of central banks.

In Chapter 3, Alain Parguez and Slim Thabet emphasize the role of the State, which was all too often forgotten by early versions of the Theory of Monetary Circuit and some post-Keynesians. They show that in a true monetary economy not doomed to permanent crises, the State must enjoy the full sovereignty of its currency by being free to create at will the money needed for achieving its goals: full employment, abolition of scarcity, building of the most enlightening future despite fundamental uncertainty.

In Chapter 4, Riccardo Bellofiore sketches Augusto Graziani's vision of the theory of the monetary circuit as a macro-class monetary theory of capitalist production, and compares it with Alain Parguez's circuitism. Bellofiore discusses the alleged differences between the two authors, before considering how Graziani dealt with the controversial problem of the 'monetization' of profit and interest. Marc Lavoie's perspective on the problem is considered, as is the criticism of Graziani's perspective put forward by Mario Seccareccia.

In Chapter 5, Giuseppe Fontana argues that John Kenneth Galbraith was first and foremost an institutionalist economist, who was in favour of the market economy, but did not hesitate to condemn its inherent problems. He believed that macroeconomic policies offered the solution to many problems and social imbalances of the modern market economies. For this reason, Fontana argues that Galbraith discussed the role of monetary and fiscal policies in a variety of theoretical and practical circumstances. Fontana critically assesses the still-dominant New Consensus Macroeconomics (NCM) theory, and its policy implications, in light of the work of John Kenneth Galbraith.

Virginie Monvoisin and Jean-Francois Ponsot, in Chapter 6, propose two specific objectives: first, what are the means by which money is not neutral? They answer this question by highlighting three dimensions of money: (i) the macroeconomic dimension of money as related to the endogeneity of money; (ii) the institutionalist dimension of money as a social relation - an institution stronger than the market; (iii) the politicaleconomy dimension of money as a source of power, asymmetries and 
conflicts. Second, they aim at showing that the macroeconomic dimension of money is the most essential prerequisite to understanding money from an economic perspective. Unfortunately, most recent widespread monetary developments (MMT, 100 per cent Money, Sovereign money, etc.) tend to focus only on holdings of money and forget that money and production are closely linked. A rehabilitation of the endogeneity of money hypothesis is then necessary.

In Chapter 7, Hassan Bougrine argues along Kaleckian lines, that the political obstacles to full employment draw their effectiveness from the strength of the oligarchic alliance between the industrialists and the financiers. The chapter builds a model to show that such strength rests on the degree of control over the process of money creation and the concomitant setting of interest rates. In this context, it is shown that the oligarchy asserts its dominance over the distribution of wealth by using both private and public means to ensure that money remains scarce - thus limiting public and private investment and job creation opportunities. To solve the long-standing problem of unemployment and break the constraint of money scarcity, the chapter proposes an economic model of generalized worker-owned enterprises and public financing entities, which would eliminate private banking and hasten the euthanasia of the rentiers.

In Chapter 8, Claude Gnos and Sergio Rossi focus on a number of essential questions about the nature of international money that have not been definitively answered by the economics profession yet. Can a national currency (such as the British pound, the US dollar, or the euro) play the role of international money essentially? What are the basics for the creation of a truly international money? Which institution should issue it? What are the links between money and credit at the international level? Is it possible to design an international monetary system conducive to financial stability as well as real economic growth?

Edwin Le Heron, in Chapter 9, starts with the argument that money is an institution, which can only function when it perfectly manages the relationship between sovereignty and confidence. The foundation of this monetary relationship can focus on either of two directions: either a topdown process based on sovereignty so as to justify public confidence in the money; or a bottom-up process starting from building confidence through coordination and learning among individuals to explain the organization of a sovereign monetary authority. Le Heron confronts two ambiguities in the monetary analysis of Keynes's General Theory. The first is the traditional opposition noted by post-Keynesians between liquidity preference and endogenous money. The second addresses the issue that when Keynes talks about interest rate, which rate is he talking about?

Chapter 10, by Thomas Ferguson, Paul D. Jorgensen and Jie Chen, 
looks at other aspects of money and finance. They argue that social scientists have traditionally struggled to identify clear links between electoral campaign finance and legislative voting. More than a few have concluded that the task is impossible. The authors address this classic question head on, starting by assembling a new data set that captures much larger swaths of politically relevant spending than any previous study - one that demonstrates how those studies have considerably underestimated flows of political money into Congress. They then analyse US House of Representatives' voting on measures to weaken the Dodd-Frank financial reform bill in the years following its passage. To control as many factors as possible that could influence floor voting by individual legislators, the analysis focus on representatives who originally cast votes in favour of the bill but then subsequently voted to dismantle key provisions of it. This design rules out from the start most factors normally advanced by sceptics to explain vote shifts, since these are the same representatives, belonging to the same political party, representing substantially the same districts. A panel analysis, which also controls for spatial influences, highlights the importance of time-varying factors, especially political money, in moving representatives to shift their positions on amendments such as the 'swaps push out' provision, which Senator Elizabeth Warren dramatically attempted, but failed, to head off. The analysis demonstrates that links between campaign contributions from the financial sector and switches to a pro-bank vote were direct and substantial: for every $\$ 100,000$ that Democratic representatives received from finance, the odds they would break with their party's majority support for the Dodd-Frank legislation increased by 13.9 per cent. Democratic representatives who voted in favour of finance often received $\$ 200,000-300,000$ from that sector, which raised the odds of switching by 25-40 per cent.

Chapter 11, by Esteban Pérez Caldentey and Matías Vernengo, wraps up the first part of the book. They argue that Lavoie and Seccareccia's work emphasized the role of rentiers, in particular their emphasis on monetary policy, building on the work of Keynes and other post-Keynesian authors, in creating conditions for higher levels of inequality, and, in turn, lower levels of economic growth. The analysis the authors propose builds on this post-Keynesian perspective, to analyse the role of financialization and international rentier interests on income distribution in Latin America. They suggest that the financialization of commodity markets, by increasing returns to what are increasingly financial assets, might have led to an increase in the profit share of several countries in the region. In this view, financialization of commodities, which went hand in hand with the neoliberal turn, plays an insidious role. While higher commodity prices, which, in part, can be ascribed to speculation in these markets, were instrumental in 
lifting the external constraint, they created the conditions, with the fluctuation and instability that characterizes financial markets, for an increased vulnerability of the region to financial crises.

Part 2, on Crises and Post-Keynesian Economics, contains six chapters. Chapter 12, by Sheila Dow, addresses the failure of mainstream economics to address an economic crisis, proving that economics itself is in crisis. She argues that, throughout their careers, Marc Lavoie and Mario Seccareccia have contributed, not only to the critique of mainstream economics, but also to building up alternative theories and theoretical frameworks better suited to addressing real macroeconomic problems. Dow focuses on the issue of how far it is feasible to establish agreement (among experts, far less the wider community) on the facts and causal mechanisms that provide the basis for macroeconomic policy. Is it a binary choice between fake news and truth?

Building on several key insights from the work of both Marc Lavoie and Mario Seccareccia to analyse the macroeconomic restrictions placed on Latin America from a circuitist perspective, Eugenia Correa and Wesley C. Marshall, in chapter 13, argue that over the last few decades, interest rate and exchange rate policies have placed the region in a straightjacket, the purpose of which was never aimed at targeting low levels of inflation, but rather low levels of growth. At the same time, the policies of deregulation and financial opening have left the region open to severe financial crises. The methodology of Lavoie and Seccareccia is adopted to critically examine the mainstream positions, and propose alternative hypotheses in the heterodox tradition. Framed in this way, it is shown how, independent of political change in the region, Latin American economies are managed following US financialized interests, which have scant interest in the region's development, much less employment and production.

Chapter 14, by Laurent Cordonnier, aims to offer an explanation - not entirely new according to the author, but revitalized and enriched - that might lend credibility to the secular stagnation viewpoint. In addition to the reasons advanced by Larry Summers and in addition to those he fails to mention (basically those long advanced by post-Keynesians), Cordonnier suggests that the persistent (structural) imbalance between the propensity to save and the inducement to invest, assuming this secular stagnation, may be the result of the malformation (or the relative weakness) of contemporary Eldorados, i.e. the disappointing nature of the new frontiers offered to the inducement to invest. He attributes this lack of Eldorados in turn to a kind of curse that clings to contemporary goods. These seem, for the time being, to be unable to combine the necessary features that would dynamically structure and coordinate supply and demand patterns so as to create, on the macroeconomic level, a virtuous loop. 
In Chapter 15, Joëlle Leclaire argues that Seccareccia and Lavoie, each in their own ways, have developed a useful discussion of the interaction between the financial and real sides of the economy, from which we have benefited in our attempt to understand how this relationship is symbiotic in nature. She considers this nexus between financial and real analysis, from the perspective of the work of Lavoie and Seccareccia. In doing so, she highlights their significant contribution to our understanding of financial crises. Specifically, she looks at Wicksell, circuit theory, the decoupling of banking and real sectors, the SFC model, endogenous money, the state, and the central bank.

Chapter 16, by Pascal Petit, claims that crises, be they financial or otherwise, tend to affect differently trade partners according to the specificities of the pattern of internationalization they are in. With an increasing still multidimensional internationalization, this spatial issue becomes an important issue if only for designing a sound governance of international exchanges, limiting the crises and their detrimental effects. Petit tries to investigate this plasticity, taking into account two characteristics for each market, namely their security and safety and applying these on both the consumer and the supplier sides. Although highly preliminary, such an approach hints at a gross assessment of the risks of crises and of their geographical diffusion.

Finally, in Chapter 17, Jan Toporowski argues that real theories of crisis, from Diamond and Dybvig, to Kiyotaki and Moore, and today's 'financialization' theorists, take a pre-finance, banking view of crisis, ultimately derived from Tugan-Baranovsky's account of banking crises in classic capitalism in Britain. Debt is viewed as a claim on real assets, and interest on the income derived from real assets. But with long-term financing, financing is secured on financial assets, and therefore prone to illiquidity in capital markets. This makes for different kind of monetary endogeneity and financial circulation, and a different kind of financial crisis.

\section{NOTE}

1. The quotes from Malinowsky, Polanyi, and Heinsohn and Steiger are taken from Wray (1990).

\section{REFERENCES}

Bougrine, H. and M. Seccareccia (2013), 'Re-thinking banking institutions in contemporary economies: are there alternatives to the status quo?'. In Rochon, 
L.-P. and M. Seccareccia, (eds), Monetary Economies of Production: Banking and Financial Circuits and the Role of the State. Cheltenham: Edward Elgar, pp. $134-159$.

Chick, V. (1986), 'The evolution of the banking system and the theory of saving, investment and interest'. Économies et Sociétés, Monnaie et Production, 3, 95-110.

Fiebeger, B. and M. Lavoie (2018), 'Helicopter ben, monetarism, the New Keynesian credit view and loanable funds', Mimeo.

Heinsohn, G. and O. Steiger (1989), 'The veil of barter: the solution to "The Task of Obtaining Representations of an Economy in which Money is Essential". In Kregel, J. (ed.), Inflation and Income Distribution in Capitalist Crisis. London: Palgrave Macmillan.

Keynes, J.M. (1971), The Collected Writings of John Maynard Keynes. Volume VI: A Treatise on Money. The Applied Theory of Money, Moggridge, D. (ed.). London: Macmillan and Cambridge University Press.

Kregel, J.A. and M. Tonveronachi (2014), 'Fundamental principles of financial regulation and supervision,' Working papers wpaper29, Financialisation, Economy, Society \& Sustainable Development (FESSUD) Project.

Innes, A. (1913), 'What is money?'. Banking Law Journal, May, 377-408.

Lavoie, M. (1992), Foundations of Post-Economic Analysis. Cheltenham: Edward Elgar.

Lavoie, M. (2004), 'The New Consensus on monetary policy seen from a postKeynesian perspective'. In Lavoie, M. and M. Seccareccia (eds), Central Banking in the Modern World: Alternative Perspectives. Cheltenham: Edward Elgar, pp. $15-34$.

Lavoie, M. (2014), Post-Keynesian Economics: New Foundations. Cheltenham: Edward Elgar.

Lavoie, M. (2020), 'Introduction'. Post-Keynesian Monetary Theory: Selected Essays. Cheltenham: Edward Elgar.

Malinowsky, B. (1922), Argonauts of the Western Pacific: An Account of Native Enterprise and Adventure in the Archipelagoes of Melanesian New Guinea. London: Routledge.

Marshall, W. and L.-P. Rochon (2019), 'Public banking and Post-Keynesian theory'. International Journal of Political Economy, 48(1), 60-75.

Monvoisin, V. and L.-P. Rochon (2006), 'The Post-Keynesian consensus, the new consensus and endogenous money'. In Gnos, C. and L.-P. Rochon (eds), Post-Keynesian Principles of Economic Policies. Cheltenham: Edward Elgar, pp. 57-77.

Polanyi, K. (1971), 'Aristotle discovers the economy'. In Polanyi, K., C. Arensberg, and H. Pearson (eds), Trade and Market in the Early Empires. Chicago: Regnery Company.

Rochon, L.-P. (1999), Credit, Money and Production: An Alternative Post-Keynesian Approach. Cheltenham: Edward Elgar.

Rochon, L.-P. (2006), 'Endogenous money, central banks and the banking system: Basil Moore and the supply of money'. In M. Setterfield (ed.), Complexity, Endogenous Money and Macroeconomic Theory: Essays in Honour of Basil J. Moore. Cheltenham: Edward Elgar, pp. 220-243.

Rochon, L.-P. and S. Rossi (2013), 'Endogenous money: the evolutionary and revolutionary views'. Review of Keynesian Economics, 1(2), 210-229.

Rochon, L.-P and M. Setterfield (2012), 'A Kaleckian model of growth and 
distribution with conflict-inflation and Post-Keynesian nominal interest rate rules'. Journal of Post Keynesian Economics, 34(3), Spring, 497-520.

Rogers, C. (1989), Money, Interest and Capital: A Study in the Foundations of Monetary Theory. Cambridge: Cambridge University Press.

Schumpeter, J. (1954/1994), History of Economic Analysis. London: Routledge.

Servet, J.M. (1994), 'La fable du troc'. Dix-Huitième Siècle, 26, 103-115.

Smithin, J. (1999), What is Money? London: Routledge.

Woodford, M. (2003), Interest and Prices: Foundations of a Theory of Monetary Policy. Princeton: Princeton University Press.

Wray, R. (1990), Money and Credit in Capitalist Economies: The Endogenous Money Approach. Aldershot, UK: Edward Elgar. 